\title{
Climate changes and methods to protect vegetable crops
}

\author{
Adriana Muscalu ${ }^{1, *}$, Cătălina Tudora ${ }^{1}$, Constantin Coța $^{1}$, Zoltan Gyorgy ${ }^{1}$, \\ Floarea Burnichi ${ }^{2}$, Mariana Bârsan ${ }^{1}$ \\ ${ }^{1}$ INMA, 6 Ion Ionescu de la Brad Blvd., Bucharest, 013811, Romania \\ ${ }^{2}$ SCDL, 23 Mesteacanului Street, Buzău, 120024, Romania
}

\begin{abstract}
In the context of the current climate change, it has become urgently necessary to develop adequate systems to protect horticultural crops. In Romania, the losses caused to these cultures by the extreme weather phenomena, as well as the lack of active intervention measures to combat or limit them, represent the main argument for addressing this field in particular. Vegetable crops are generally sensitive to extreme weather phenomena. In the climatic conditions in our country, the extreme phenomena occur between March and September, which coincides with the vegetation period of the crops. Of these, hail causes significant damage, and in some cases, at high intensity and long-lasting, can cause the calamity of vegetable crops. Another effect can arise in the drought years, when, in the absence of rainfall, the weeds enter into a fierce competition with vegetables, as regards the specific consumption of water and nutrients. The paper presents a review regarding the current methods of vegetable crops protection against the extreme weather phenomena and of weed control in these crops, grown in organic system. Combining the available solutions, adopting integrated strategies for non-chemical weed control can be an important premise for researchers and farmers to protect vegetable crops.
\end{abstract}

\section{Introduction}

In recent years, an increasing importance has been given to the study of climate change, due to the negative effects generated on natural ecosystems, human health and the economy. The global warming, manifested by the increase in average and extreme temperatures of the air has been demonstrated by numerous studies carried out in different regions of the globe, during several decades $[1,2,3,4]$. This has resulted in an increase in the humidity level of the atmosphere, increasing the intensity and frequency of negative events related to extreme precipitation, which is one of the most variable climatic elements [5].

The monitoring of extreme climatic events at the annual and seasonal scale is particularly important for the creation of protection or intervention means to reduce the losses caused by such manifestations [6]. In countries where agriculture is one of the main branches of the economy, as is the case in Romania, extreme climate phenomena

* Corresponding author: amuscalis@yahoo.com 
have a profound impact [7]. Of these, hail storms are severe convective weather events that occur frequently in Central Europe during the summer, most being confined to continental Europe, where convective energy is the highest $[8,9]$.

In our country, about $60 \%$ of the storms that occur between March and September are accompanied by hail falls [6]. The occurrence interval coincides with the vegetation period of most crops and the intensity of the phenomenon determines the degree of their calamity [10].

Vegetables play an important role in ensuring food and nutritional security, being one of the richest sources of vitamins and minerals. Vegetable crops are highly perishable and sensitive to unpredictable as well as extreme climate changes, which affect them in terms of quantity and quality of production, as well as the severity of environmental stress [11]. Depending on the vegetation phase of vegetable crops, hail can cause not only a drop, but even a complete loss of crops.

Also, compared to other crops, vegetables are highly sensitive to weed attack, which is a top concern among organic vegetable producers [12]. Crop protection and weed control in organic vegetable crops are major challenges for farmers.

The purpose of the paper is a presentation of the current state of protection methods against the negative effects caused by climate change for organic vegetable crops.

\section{Methods of vegetable crop protection}

Due to the frequency and adverse effects of hail falls, the most used protection systems are those against this extreme phenomenon.

\subsection{Anti-hail protection methods}

Protection methods include active and passive hail control methods.

\subsubsection{Active control methods}

Different methods, equipment and technologies have been used over time to reduce hail effects. Modern solutions aim at the protection of large areas, allowing the automation and mathematical modeling of processes [13]. Active control methods are based on: seeding of clouds with silver iodide or other substances, which causes freezing at higher temperatures, respectively the use of hail cannons or other types of explosive devices. These involve the generation of significant supersonic shock waves, directed to the sky, to transport the positive ions from the ground level to the cloud level, disrupting the formation of hail nuclei $[13,14,15]$. For the methods to be effective, the timing of their start-up is very important $[13,14]$. These methods achieve anti-hail protection by: prevention of hail formation in advance or stopping the further growth of small ice particles in the clouds and by suppressing, stopping the growth of small and moderate hailstones, by stopping the melting of hail particles nuclei $[14,15]$. The simplest method of introducing silver iodide into the clouds is to use generators, located on the ground and manually operated. The operation can also be performed by plane at the right time and place, except for heavy clouds. The method of seeding the clouds made with rocket-type devices is much more accurate and efficient, being also used in Romania. Most European countries have anti-hail systems, using the last two methods, sometimes in combination, according to national or regional strategies [13]. In order to increase the efficiency of the national anti-hail system, the research aimed at its complementary equipment, such as the anti-hail rocket launcher monitoring system [16]. 


\subsubsection{Passive control methods}

These methods refer to plant cover systems, which prevent or reduce hail physicomechanical impact on them. The use of these systems, generally made up of the protective net and the resistance structure that supports it, requires significant investments for farmers, but in the longer term. Thus, for a culture, the structure of resistance and fixation can be used approx. 15-20 years, and the net approx. 3-4 years, or more, depending on its characteristics [14].

Agricultural crops, especially horticultural ones, are often protected by "nets" against: excessive solar radiation (shade nets), pests (insects, birds, fruit bats) or extreme weather phenomena (hail, wind, frost), depending on mesh size. These textile materials can be applied as a single coating or combined with other types of materials, as in the case of greenhouses [17]. These "nets", increasingly used for horticultural crops, are part of the socalled agrotextiles, whose generic name is used to classify the woven, nonwoven and knitted textile materials used in agriculture [18]. This sector of the economy faces many problems, as we have shown above, and these materials can offer multidimensional points of view and solutions to some of them [19]. Agrotextiles are an important segment of technical textiles, which due to their mechanical properties, high resistance to environmental factors, light processing capacity and durability can improve the yield, quality and safety of agricultural crops and products $[18,19]$.

In general, the advantages of using agrotextiles are: increasing agricultural production, avoiding soil drying, reducing fertilizer, pesticide and water requirements, improving product quality, increasing early maturity of non-seasonal plants, protecting against climate change and their effect [18].

Agrotextiles can be classified according to several criteria such as: the way the textile material is made (woven, knitted or non-woven), application field (agriculture, horticulture, forestry, aquaculture, animal husbandry), purpose pursued (anti-hail protection, protection against birds, insects, for shade, mulch-type mats, etc.) [18, 19]. Synthetic fibres (polyethylene, polypropylene, polyester, nylon) are widely used for their manufacture. The commonly used synthetic polymers are tape, monofilament and multifilament yarn. Natural fibres (wool, jute, cotton), although they have a much shorter lifespan compared to synthetic ones, are only used for certain purposes, when their properties related to good moisture retention, better insulation under humidity conditions, maintaining the constant temperature of the soil without generating the effect of wind tunnel, biodegradability, etc. are exploited $[18,20]$.

Agrotextiles are technically made, depending on their destination. Thus, those for protection against hail are lightweight, made with mesh (nets), resistant to breakage and exposure to ultraviolet radiation, to prevent crop defoliation. Usually, these nets are made of polyethylene monofilament and do not restrict plants' development [21, 22]. Textiles designed to reduce the effect of the wind can improve the quality of the plants' development by minimizing their damage and shaking. The ones used for shading are made of polypropylene monofilament slivers, in both woven and knitted form. Each plant has its own requirements for optimum development, the balance between them and the environmental conditions, can only be achieved through a correct choice of coverage [22]. In addition, agrotextiles prove their adaptability and flexibility in various locations and geographical areas [21].

The efficient application of light is essential for the growth of plants, all aspects of their development being sensitive to it. Horticulturists are studying the possibility of selective modification or activation of plants' existing features depending on the light, in order to increase the productivity and quality of the crops [23].

Following the researches, for some vegetable crops, by using photoselective nets, which have chromatic elements incorporated by an innovative technology, specific 
physiological and horticultural benefits were obtained, in addition to the initial protection ones, presented previously $[17,24]$. In the case of sweet peppers, the use of red and yellow nets increased productivity. In addition, in their case, an increased accumulation of antioxidants was observed for the yellow mesh [24].

\subsection{Weed control in organic vegetable crops}

Weed management is a major concern for organic vegetable producers. These crops are more susceptible to weeds than the arable ones, because of their low competitive capacity, and the strategies and techniques used are established according to the crop, climate, soil technology $[25,26,27]$. For this type of crops, it is necessary to apply an integrated system of non-chemical weed control methods, and it is necessary to approach as many of them as possible in order to obtain efficient results $[25,27]$. The classification of these methods can be done in the general way or by customizing according to the type of crop [25, 26, 27]. Since vegetable crops in ecological system fall into the minor crops, we present a nonchemical weed control strategy proposed for them [26].

\subsubsection{Agricultural practices - preventive measures}

Prevention refers to the ways in which the danger of introducing new weed species is reduced. In this case, hygiene conditions are required for the seed material or the seedlings used, for the equipment and soil. It can be disinfected with steam or steam and organic substances, such as zeolites (potassium hydroxide and carbon oxide), using the Bioflash system. Soil heating is a promising, preventive ecological method of weed control in niche crops, which bring high incomes, such as vegetables and flowers [28, 29, 30]. Crop rotation must be diversified by adding crop species with different life cycles. Their associated management under different environmental conditions, has an effect on the control of weed populations or causes the reduction of the weed seed bank in the soil $[31,32]$. Primary tillage and seedbed preparation can have important effects on the dynamics of the weed communities, if the weather conditions are considered (temperature, precipitation), and facilitate the mechanical control [26, 33, 34, 35]. Fertilization contributes to reducing the use of herbicides and increasing crop production, but the variation in dosages, the application methods, combinations and types of fertilizers used must be adapted to maintain the biodiversity of weed communities in an agroecosystem, protecting the environment. [36, 37]. Vegetable varieties are chosen based on resistance to biotic and abiotic stress factors, as well as productivity and quality. Some of them due to their general size or leaf size can be competitive against the weeds, preventing the germination of their seeds $[38,39]$.

\subsubsection{Control by physical means (mechanical or thermal)}

For the mechanical control, together with the equipment fitted with classic active parts, the one equipped with new types of environmentally friendly active parts (e.g. brush weeder with horizontal or vertical axis, basket weeder, finger weeder etc.) or combinations between types of active parts can be used. Table 1 presents the characteristics of certain types of equipment intended for mechanical control between rows that can be used for any type of crop, including vegetable crops [26,40]. 
Table 1 Features of inter-row mechanical weed tools [26]

\begin{tabular}{|c|c|c|c|c|c|c|c|}
\hline $\begin{array}{c}\text { Inter-row } \\
\text { mechanical } \\
\text { weed } \\
\text { control } \\
\text { tools }\end{array}$ & $\begin{array}{c}\text { Weeding } \\
\text { action }\end{array}$ & $\begin{array}{c}\text { Work } \\
\text { ing } \\
\text { depth }\end{array}$ & $\begin{array}{c}\text { Soil } \\
\text { texture }\end{array}$ & $\begin{array}{c}\text { Inter- } \\
\text { row } \\
\text { distance }\end{array}$ & $\begin{array}{l}\text { Optimum } \\
\text { weed } \\
\text { growth } \\
\text { stage }\end{array}$ & $\begin{array}{l}\text { Optimum } \\
\text { crop } \\
\text { growth } \\
\text { stage }\end{array}$ & $\begin{array}{c}\text { Work } \\
\text { capacity } \\
\left(\text { ha h }^{-1}\right) / \\
\text { Working } \\
\text { width }\end{array}$ \\
\hline $\begin{array}{l}\text { Traditional } \\
\text { hoe (with } \\
\text { tine } \\
\text { cultivators) }\end{array}$ & $\begin{array}{c}\text { uprooting } \\
\text { cutting } \\
\text { and } \\
\text { burying }\end{array}$ & $\begin{array}{c}30-50 \\
\mathrm{~mm}\end{array}$ & $\begin{array}{l}\text { both clay } \\
\text { (with } \\
\text { rigid } \\
\text { shanks) } \\
\text { and } \\
\text { sandy } \\
\text { (flexible } \\
\text { shanks) } \\
\text { soils }\end{array}$ & $\begin{array}{l}\text { from } \\
0.20- \\
0.25 \mathrm{~m} \\
\text { to } 0.50 \\
\mathrm{~m}\end{array}$ & $\begin{array}{c}\text { from } 4 \text { to } 6 \\
\text { true leaves } \\
\text { stage }\end{array}$ & $\begin{array}{c}\text { from } \\
\text { cotyledon } \\
\text { stage (with } \\
\text { shanks) or } \\
\text { from } 4 \\
\text { true-leaves } \\
\text { stage until } \\
\text { the } \\
\text { treatment is } \\
\text { carried out } \\
\text { without } \\
\text { crop injury }\end{array}$ & $\begin{array}{c}0.5 / 1.5 \\
\mathrm{~m}\end{array}$ \\
\hline Rotary hoe & $\begin{array}{c}\text { uprooting } \\
\text { and } \\
\text { burying }\end{array}$ & $\begin{array}{c}40-50 \\
\mathrm{~mm}\end{array}$ & $\begin{array}{l}\text { better in } \\
\text { loose } \\
\text { soils }\end{array}$ & $\begin{array}{c}\text { from } \\
0.40 \mathrm{~m} \\
\text { to } 0.50- \\
0,75 \mathrm{~m}\end{array}$ & $\begin{array}{c}\text {-from } \\
\text { cotyledon } \\
\text { to } 4 \text { true- } \\
\text { leaves } \\
\text { stage } \\
\text {-low } \\
\text { effectivene } \\
\text { ss on grass } \\
\text { and } \\
\text { perennial } \\
\text { weed } \\
\text { species }\end{array}$ & $\begin{array}{c}\text { from } \\
\text { cotyledon } \\
\text { stage (with } \\
\text { shanks) or } \\
\text { from } 4 \\
\text { true-leaves } \\
\text { stage until } \\
\text { the } \\
\text { treatment is } \\
\text { carried out } \\
\text { without } \\
\text { crop injury }\end{array}$ & $1.5 / 3 \mathrm{~m}$ \\
\hline $\begin{array}{l}\text { Rotary } \\
\text { tilling } \\
\text { cultivators } \\
\text { (with } \\
\text { multiple } \\
\text { heads) }\end{array}$ & $\begin{array}{c}\text { uprooting } \\
\text { lacerating } \\
\text { and } \\
\text { burying }\end{array}$ & $\begin{array}{c}40-60 \\
\mathrm{~mm}\end{array}$ & $\begin{array}{l}\text { both clay } \\
\text { and } \\
\text { sandy } \\
\text { but not } \\
\text { stony } \\
\text { soils }\end{array}$ & $\begin{array}{c}\text { from } \\
0.30 \mathrm{~m} \\
\text { to } 0.40- \\
0.50 \mathrm{~m}\end{array}$ & $\begin{array}{c}\text { from } \\
\text { cotyledona } \\
1-2 \text { true- } \\
\text { leaves } \\
\text { stage to } \\
\text { well- } \\
\text { developed } \\
\text { weeds }\end{array}$ & $\begin{array}{c}\text { from } 2 \\
\text { true-leaves } \\
\text { stage until } \\
\text { the } \\
\text { treatment is } \\
\text { carried out } \\
\text { without } \\
\text { crop injury }\end{array}$ & $\begin{array}{c}0.3 / 1.5 \\
\mathrm{~m}\end{array}$ \\
\hline $\begin{array}{l}\text { Horizontal } \\
\text { brush } \\
\text { weeder }\end{array}$ & $\begin{array}{c}\text { uprooting } \\
\text { and } \\
\text { drying } \\
\text { weeds on } \\
\text { the soil } \\
\text { surface }\end{array}$ & $\begin{array}{c}10-30 \\
\mathrm{~mm}\end{array}$ & $\begin{array}{c}\text { better in } \\
\text { loose, } \\
\text { flat and } \\
\text { not } \\
\text { compact } \\
\text { ed soils }\end{array}$ & $\begin{array}{l}\text { from } \\
0.20- \\
0.25 \mathrm{~m} \\
\text { to } 0.40 \\
\mathrm{~m}\end{array}$ & $\begin{array}{c}\text { from } \\
\text { cotyledon } \\
\text { to } 4 \text { true- } \\
\text { leaves } \\
\text { stage -also } \\
\text { weeds very } \\
\text { close to } \\
\text { crop row }\end{array}$ & $\begin{array}{l}\text { from } \\
\text { cotyledon } \\
\text { stage until } \\
\text { the } \\
\text { treatment is } \\
\text { carried out } \\
\text { without } \\
\text { crop injury }\end{array}$ & $\begin{array}{c}0.4 / 1.5 \\
\mathrm{~m}\end{array}$ \\
\hline Split-hoe & $\begin{array}{l}\text { cutting, } \\
\text { uprooting } \\
\text { and } \\
\text { drying } \\
\text { weeds on } \\
\text { the soil } \\
\text { surface }\end{array}$ & $\begin{array}{c}10-40 \\
\mathrm{~mm}\end{array}$ & $\begin{array}{l}\text { both clay } \\
\text { and } \\
\text { sandy } \\
\text { but not } \\
\text { stony } \\
\text { soils }\end{array}$ & $\begin{array}{l}\text { from } \\
0.20- \\
0.25 \mathrm{~m} \\
\text { to } 0.40 \\
\mathrm{~m}\end{array}$ & $\begin{array}{c}\text { from } \\
\text { cotyledon } \\
\text { to } 6-8 \text { true- } \\
\text { leaves } \\
\text { stage also } \\
\text { weeds very } \\
\text { close to } \\
\text { crop row }\end{array}$ & $\begin{array}{l}\text { from } \\
\text { cotyledon } \\
\text { stage until } \\
\text { the } \\
\text { treatment is } \\
\text { carried out } \\
\text { without } \\
\text { crop injury }\end{array}$ & $\begin{array}{c}0.4 / 1.5 \\
\mathrm{~m}\end{array}$ \\
\hline
\end{tabular}


The mechanical equipment together with the thermal one for weed control are intensively used both in organic vegetable crops and in the conventional ones, because of the strict European legislation regarding the chemical substances of protection. These devices, which have been continuously developed, represent the traditional physical means used in the non-chemical weed control [41].

Regarding thermal control, it is based on the transfer of heat between equipment and plants, the contact being foliar. The specialized equipment is based on the action of: hot air, steam, hot water, saturated steam, infrared radiation, flames, laser, etc. The efficiency of the treatment depends on the amount of heat transferred, the exposure period, as well as the development stage of weeds, the younger ones being more vulnerable. Drying of plants after exposure to heat occurs because of the expansion of intracellular water, which causes the breakdown of cell membranes, young weeds being vulnerable to this [42, 43, 44]. Most used are open flame burners: atmospheric and self-vaporizer, which can have various forms (cylindrical, truncated-conic, prismatic, or truncated-pyrmidal), being powered by propane or LPG in gaseous or liquid phase [40]. For high efficiency, they have a position inclined to the vertical, the distance to the soil, respectively to the crop plant, being important [44].

Numerous researches have been made regarding the combined use of the two methods presented above, in order to increase the efficiency of the control operation [45, 46, 47]. Thus, a combined flamer-cultivator was used to control weeds in an asparagus crop, before mechanically harvesting it. The new machine achieved a satisfactory level of weed control, for a consumption of 43-87 $\mathrm{kg} \mathrm{ha}^{-1} \mathrm{LPG}$, being especially effective on weeds in the early stages. This method can be introduced as an ecological alternative for weed control in asparagus cultivation technology, before and after harvesting it. [47].

In order to effectively control weeds, intelligent systems carry out: guiding the control devices (mechanical or thermal), detecting and identifying the weeds, eliminating them and possibly mapping them. At this moment only a few companies make and sell automatic machines for mechanical weed control: Robovator (Frank Poulsen Engineering ApS Denmark); Robocrop (Garford Ltd. United Kingdom), IC-Cultivator (Machinefabriek Steketee BV - Netherlands), Remoweed (Costruzioni Meccaniche Ferrari -Italy) [26, 40]. They have been tested in several working conditions.

The active parts of Rovobator are a pair of knives that move 1-2 cm below the ground, closing and opening according to the order received from a hydraulic servomotor connected to a camera mounted in front of it. The identification of the plants in the crop is based on colour, size and spacing $[48,49]$. A computer processes the images and calculates the points at which the cutting blades need to be activated depending on the speed and location of the crop plants. For larger working widths, several such modules are mounted on a frame [48]. Thus, in a lettuce crop, Robovator removed 18 to $41 \%$ more weeds from areas with moderate to high densities and reduced the weeding time by 20 to $45 \%$ compared to the standard cultivator, but in an onion crop it did not have a satisfactory yield $[48,50]$. The Rovobator system is also made in the variant for thermal control, which uses the same plant recognition system as for mechanical control. This machine is based on the serial application of a propane-powered flame. As the flame system passes over a weed, the viewing system controls the ignition of the burners, so that a weed will be exposed to the heat of the flame several times. The viewing system extinguishes the flame when passing over the crop plants, the working speed of the equipment is $1-6 \mathrm{~km} \mathrm{~h}^{-1}$ [49].

The IC-Cultivator, has a similar construction, the blades actuated by two pneumatic cylinders, performeds a cutting capacity of 3 - 4 plants / second, at a working speed of maximum $5 \mathrm{~km} \mathrm{~h}^{-1}$. Robovator and IC Cultivator were tested in lettuce thinning, achieving a level of $5.6 \%$ because of the small size of the plants, as well as of the operating mode, based on the recognition of vegetable plants. They achieved a satisfactory weeding level, in a shorter time by $37.1 \%$ compared to the manual one [51]. 
An automatic system of thermal control with hot oil used against the black nightshade and red-root weeds was studied in an early tomato crop. To a hyperspectral imaging system, based on a multispectral Bayesian classifier, a precision micro-metering system with pulsed pulses was coupled to provide organic oil at $160{ }^{\circ} \mathrm{C}$. In the range $384-810 \mathrm{~nm}$, weed species were discriminated in an average proportion of $95.9 \%$. The oil was sprayed over the weeds, the doses applied on the target being about $0.85 \mathrm{mg} \mathrm{cm}^{-2}$, in $10 \mathrm{~ms}$ pulsed doses, during the movement with a speed of $0.04 \mathrm{~m} \mathrm{~s}^{-1}$. After 15 days, the black nightshade was destroyed $95.8 \%$ and red-root $93.8 \%$, while only $2.4 \%$ of tomato plants were affected by the thermal agent. [52].

\subsubsection{Mulching}

It is a physical method used in the strategy of weed control in vegetable crops, consisting of the application on the soil of a layer of organic or synthetic matter, being effective especially against annual weeds. Organic mulch (cereal straw, leaves, pine needles, etc.) is most often used in organic crops because it can improve soil properties. For tomato and eggplant crops, polyethylene mulches are used, which ensure a lower soil temperature than the transparent one, preventing sunlight from entering and implicitly weed development [26].

\section{Conclusions}

In general, the only way to mitigate the negative impact of climate change on vegetable production, especially on their productivity, quality and yield, is to take effective measures. Crop protection against extreme weather events and weed management improvement are also among the efficient adaptation strategies, which include: the development of heat and salinity tolerant varieties, as well as flood resistant, drip irrigation, soil and moisture conservation measures, fertilizer management, etc.

Combating harmful plants in organic vegetable crops can be solved only by combining available solutions and adopting an integrated non-chemical weed management strategy. As for specialized equipment, it seems that small innovative companies will develop new weed control technologies, because based on the progress made, the future in this field belongs to automatic systems.

It is important for future research to focus on the shortcomings or weaknesses of systems and methods related to reducing the negative impact of climate change on organic vegetable crops, in order to provide farmers with viable strategies and solutions.

"The work was supported by grant of the Romanian Ministry of Research and Innovation, CCCDI UEFISCDI project number PN-III-P1-1.2-PCCDI-2017-0659 / No.11 PCCDI/2018, within PNCDI III and a grant of the Romanian Education and Research Ministry, through Programme 1 - Development of the national research-development system, subprogramme 1.2 - Institutional performance Projects for financing excellence in RDI, contract no. 16PFE."

\section{References}

1. A. El Kenawy, J.I. Lopez-Moreno, S. M. Vicente-Serrano, Recent trends in daily temperature extremes over northeastern Spain (1960-2006), Nat. Hazards Earth Syst. Sci., 11, 21,(2011);

2. A. E. Croitoru, A. Piticar, Changes in daily extreme temperatures in the extra-Carpathians regions of Romania, International Journal of Climatology, 33, 15, (2013); 
3. Q. Wang, X. Fan, Z. Qin, M. Wang, Change trends of temperature and precipitation in the Loess Plateau Region of China, 1961-2010, Global and Planetary Change, 92-93, 10, (2012);

4. A. R. Scorzini, M. Di Bacco, M. Leopardi, Recent trends in daily temperature extremes over the central Adriatic region of Italy in a Mediterranean climatic context, International Journal of Climatology, 38, (S1), 17, (2018);

5. E.B. Lupikasza, S. Hänsel, J. Matschullat, Regional and seasonal variability of extreme precipitation trends in southern Poland and central-eastern Germany 1951-2006, International Journal of Climatology 31, 23, (2011);

6. C. Şulea-Iorgulescu, Researches on the development of an integrated computer system for monitoring the anti-hail rockets launch units, Universitaria Publishing House, Craiova, Romania, ISBN 978-606-14-0833-7 (2014);

7. A. Piticar, PhD thesis - Studies on recent climate change in Northeastern Romania, University "Babes-Bolyai" Cluj Napoca (2013);

8. S. Mohr, M. Kunz, Recent trends and variabilities of convective parameters relevant for hail events in Germany and Europe, Atmospheric Research on ScienceDirect 123, 18, (2013);

9. H. J. Punge, K. Bedka, M. Kunz, A. Werner, A new physically based stochastic event catalog for hail in Europe, Natural Hazards 73, 21, (2014);

10. K. A. Nicolaides, G. Photiou, K. Savvidou, A. Orphanou, S. C. Michaelides, T. S. Karakostas , D. Charalambous, C. Kannaouros, The impact of hail storms on the agricultural economy of Cyprus and their characteristics, Adv. Geosci., 17, 5, (2009);

11. A. Pushparani Devi, Moirangthem Sanju Singh, Shubhashree Priyadarshinee Das, Jhilki Kabiraj, Effect of Climate Change on Vegetable Production- A Review, Int. J. Curr .Microbiol. App. Sci. 6(10), 7, (2017);

12. E. E. Braun, S. Taylor Lovell, M. Babadoost, F. Forcella, S. Clay, D. Humburg, S. E. Wortman, Abrasive grit application in organic red pepper: An opportunity for integrating nitrogen and weed management, HortScience 54 (9), 8, (2019);

13. D. Zugravescu, Gh. Manolea, L. Alboteanu, C. Şulea Iorgulescu, Anti-hail system geonomic component of modern science, Proceedings of the International Conference on RISK MANAGEMENT, ASSESSMENT and MITIGATION, 5, ISSN: 1790-2769, ISBN: 978-960-474-182-3 (2010);

14. A. K. Arakelyan, Flaws and advantages of current and prospective anti-hail protection methods, stations and networks (Review), Global Advanced Research Journal of Agricultural Science (GARJAS) 7(12), 11 (2018);

15. A. K. Arakelyan, A Way to Enhance Hail Prevention Technique and to Increase the Efficiency of Anti-Hail Protection of Unlimited Agricultural Areas, J Agron Agri Sci 2: 013 (2019);

16. G. Manolea, I.L. Alboteanu, A. Novac, C. Sulea Iorgulescu, S. Stepan, Optimizing the Structure of the Rocket Launcher Monitoring System, 2019 International Conference on Electromechanical and Energy Systems (SIELMEN), Craiova, Romania, 5, (2019);

17. Y. Shahak, Photoselective Netting: The Concept, Research and Implementation in Various Crops, ASHS Annual Conference, 8, (2011);

18. S. K. Agrawal, Application of textile in agriculture, IJARSE 2 (7), 10, (2013);

19. E. Cărpuş, A Dorogan, F. Burnichi, Agrotextile Systems - Strategic Elements for Sustainable Development of the Agriculture, 7-th International Conference on Advanced Materials and Systems ICAMS, 5, (2018); 
20. K. Bhavani, N. Mallikarjun, N.M. Sunilkumar, Agro textiles - Their applications in agriculture and scope for utilizing natural fibers in agro tech sector, International Journal of Applied Home Science, 4 (7\&8), 10, (2017);

21. S. G. Annapoorani, K. Saranya, Applications of Agricultural Textiles - A Review ,International Journal for Research in Engineering Application \& Management (IJREAM), 4, ISSN: 2454-9150 Special Issue - ICDOMP'19, 4, (2019);

22. P. Marasovic, D. Kopitar, Overview and perspective of nonwoven agrotextile, TEXT LEATH REV 2 (1), 14, (2019);

23. M.A. Jones, Using light to improve commercial value, Horticulture Research 5, 47 (2018);

24. Y. Shahak, Y. Kong, K. Ratner, The wonders of yellow netting, Acta Hortic. 1134, 8, (2016);

25. B. P. Baker, C. L. Mohler, Weed management by upstate New York organic farmers: strategies, techniques and research priorities, Renewable Agriculture and Food Systems, 30 (5), 10, (2014);

26. E. Pannaci, B. Lattanzi, F. Tei, J., Non-chemical weed management strategies in minor crops: A review, Crop Protection 96, 15, (2017);

27. B. Melander, N. Holst, I. A. Rasmussen, P. K. Hansen, Direct control of perennial weeds between crops e Implications for organic farming, Crop Protection 40, 7, (2012);

28. A. Peruzzi, M. Raffaelli, M. Ginanni, M. Fontanelli, C. Frasconi, An innovative selfpropelled machine for soil disinfection using steam and chemicals in an exothermic reaction, J. Biosystem Engineering 110, 9, (2011);

29. A. Peruzzi, M. Raffaelli, C. Frasconi, M. Fontanelli, P. Bàrberi, Influence of an injection system on the effect of activated soil steaming on Brassica juncea and the natural weed seedbank J. Weed Research, 52, 13, (2012);

30. M. Raffaelli, L. Martelloni, C. Frasconi, M. Fontanelli, S. Carlesi S., A. Peruzzi, A prototype band-steaming machine: Design and field application, J. Biosystem Engineering 144, 11, (2016);

31. A. Koocheki, M. Nassiri, L Alimoradi, R. Ghorbani, Effect of cropping systems and crop rotations on weeds, Agron. Sustain. Dev. 29, 8 (2009);

32. D. Weisberger, V. Nichols, M. Liebman M, Does diversifying crop rotations suppress weeds? A meta-analysis, PLoS ONE 14(7): e0219847, (2019);

33. S. Cordeau, R. G. Smith, E.R. Gallandt, B. Brown, P. Salon, A. DiTommaso, M.R. Ryan, Disentangling the Effects of Tillage Timing and Weather on Weed Community Assembly, J. Agriculture 7 (8), 66, 18, (2017);

34. S. Gruber,W. Claupein Effect of tillage intensity on weed infestation in organic farming, J. Soil \& Tillage Research 105, 8, (2009);

35. M. H. Jorgensen Chapter 3, The Effect of Tillage on the Weed Control: An Adaptive Approach, Biological Approaches for Controlling Weed, (2018) http://dx.doi.org/10.5772/intechopen.76704;

36. L.Tang, C. Cheng, K. Wan, R. Li, D. Wang, Y. Tao, Impact of Fertilizing Pattern on the Biodiversity of a Weed Community and Wheat Growth, PLoS ONE 9(1): e84370., (2014);

37. A. A. Bajwa, Ehsanullah, S. A. Anjum, W. Nafees, M. Tanveer, H. S. Saeed, Impact of fertilizer use on weed management in conservation agriculture - A Review, Pakistan J. Agric. Res. 27(1), 10 (2014); 
38. R.K. Dhall, Breeding for Biotic Stresses Resistance in Vegetable Crops: A Review, STM Journals 2015, RRJoCST 4 (1), 14, (2015);

39. P. Dittmar, N. Boyd, R. Kanissery, Weed Management Principles in Commercial Vegetable Production, HS717/CV113, 6, (2018);

40. A. Peruzzi, L. Martelloni, C. Frasconi., M. Fontanelli, M. Pirchio, M. Raffaelli, Machines for non-chemical intra-row weed control in narrow and wide-row crops: a review, Journal of Agricultural Engineering, XLVIII:583, 14, (2017);

41. D.L. Shaner, H.J. Beckie H.J., The Future for Weed Control and Technology, Pest Management Science 70 (9), 11 (2014);

42. J. Banks, G. Sandral, Report on weed control using hot water/steam and herbicides in the city of Joondalup, (2007)

http://api.joondalup.wa.gov.au/files/councilmeetings/2007/attach11brf210807.pdf;

43. A. M. Peerzada, B. S. Chauhan, Thermal Weed Control: History, Mechanisms, and Impacts in Jabran K., Chauhan B.S. (Eds) Non - Chemical Weed Control, Elsevier, Academic Press, 23, (2018);

44. J. Ascard, Effect of flame weeding on weed species at different developmental stages, Weed Res. 35, 15, (1995);

45. L. Martelloni, C. Frasconi, M. Fontanelli, M Raffaelli, A. Peruzzi, Mechanical weed control on small-size dry bean and its response to cross-flaming, SJAR 14 (1), 12, (2016);

46. M. Raffaelli, M. Fontanelli, L. Martelloni, C. Frasconi, A. Peruzzi, Innovative strategy and machines for physical weed control in agriculture and urban areas, International Conference RAGUSA SHWA, Italy, 7, (2012);

47. L. Martelloni, M. Fontanelli, C. Frasconi, M. Raffaelli, M. Pirchio, A. Peruzzi, A combined flamer-cultivator for weed control during the harvesting season of asparagus green spears, SJAR 15 (2), 10, (2017);

48. B. Melander, B. Lattanzi,E. Pannacci, Intelligent versus non-intelligent mechanical intra-row weed control in transplanted onion and cabbage, J. Crop Protection 72, 8, (2015)

49. M, Siemens, Robotic Weed Control, Proceedings of the California Weed Science Society 66, 5, (2014);

50. R. Lati, M. Siemens, J. Rachuy, S. Fennimore, Intra-Row Weed Removal in Broccoli and Transplanted Lettuce with an Intelligent Cultivator, Weed Technology 30 (3), 9, (2016);

51. R. Smith, Evaluation of intelligent cultivators for use in lettuce production, UC Weed Science, ANR Blogs, (2016), https://ucanr.edu/blogs/blogcore/postdetail.cfm?postnum $=19841 \&$ email $=$ yes;

52. Y. Zhang, E. S. Staab, D. C. Slaughter, D. K. Giles, D. Downey, Automated weed control in organic row crops using hyperspectral species identification and thermal micro-dosing, J. Crop Protection 41, 10 (2012); 